\title{
The Neo-Christian Bias and Its Discontents: Milton Studies and the Case of Samson Agonistes
}

\section{ELIZABETH}

SAUER

\begin{abstract}
Résumé : Les études miltoniennes ont été dominées par ce que John Rumrich qualifie de "Milton inventé », personnage caractérisé par son didactisme et son orthodoxie d'après le "préjugé néo-chrétien » de la critique. Rumrich emprunte cette dernière expression à William Empson, qui, il y a des décennies, mit en cause la tendance à imposer sur Milton la cohérence et l'orthodoxie religieuse. Dans cette exercice d'analyse, l'auteur examine l'engagement de Milton avec l'hétérodoxie et l'hérésie dans Samson Agonistes, poème dont la réception a été déterminée par les «piétés régénératrices » des spécialistes ayant pris un parti conservateur.
\end{abstract}

\section{I}

Milton studies has been dominated by what John Rumrich calls "the Invented Milton," a figure defined by his didacticism and orthodoxy, characteristics Rumrich ascribes to the "neo-Christian" bias of Milton criticism. ${ }^{1}$ Rumrich borrows this phrase from William Empson, who decades ago exposed the impetus to read Milton into coherence and religious conservatism. Far from being an indictment of Christianity at large, the term "Neo-Christian" is directed at "literary critics, some of whom believe in Christianity and some not, who interpret any literary work they admire by finding in it a supposed Christian tradition." "Within this context, the "Christian tradition" is aligned with conservatism and becomes the interpretive lens through which literary works are read into conformity. Both Empson and Christopher Hill - the latter also invoked by Rumrich as one who took issue with the conservatism of Milton criticism - identify C. S. Lewis as leading the charge to "annex Milton for 'orthodoxy,", as Hill puts it. ${ }^{3}$ Milton's poetry best lends itself, 
according to Lewis, to interpretations by those who count themselves among Milton's fit (Christian) readers: "In order to take no unfair advantage I should warn the reader," cautions Lewis, "that I myself am a Christian. . . . But for the student of Milton my Christianity is an advantage. What would you not give to have a real, live Epicurean at your elbow while reading Lucretius?"4 Lewis's influential contributions to Milton studies bestowed a long life on the invented Milton made in the image of the neo-Christian critic, and Empson contends with Lewis throughout Milton's God. ${ }^{5}$ Even today readers of Milton maintain that "Milton is a writer to portray for us only his certainties, never his doubts; to advertise only his constancies, never his changes of mind." 6

In his most recent book, How Milton Works, Stanley Fish justifies approaches that defend Milton's will-to-order, asserting that "conflict, ambivalence, and open-endedness - the watchwords of a criticism that would make Milton into the Romantic liberal some of his readers want him to be - are not constitutive features of the poetry but products of a systematic misreading of it."7 "Milton criticism," he observes, "sometimes offers us the choice between an absolutist poet with a focused vision and a single overriding message and a more tentative, provisional poet alert to the ambiguities and dilemmas of the moral life. The truth is that Milton is both, and is so without either contradiction or tension. He never wavers in his conviction that obedience to God is the prime and trumping value in every situation." 8 Milton studies, "especially of late," "has been paralyzed, indeed impoverished, by the suppression of such conflicts or just plain avoidance of them" - an observation Joseph Wittreich made in 1997 and reiterated at the start of Shifting Contexts: Reinterpreting Samson Agonistes (2002). ${ }^{9}$

Still, the practice of reading Milton into orthodoxy has not gone unchallenged, as the example of Wittreich shows. But even decades earlier, Christopher Hill opposed the religious conservatism and methodological prudence in Milton studies by transforming the poet-revolutionary into "a radical Protestant heretic.” Hill summarizes Milton's heterodoxy, reminding us that the poet-revolutionary

rejected Catholicism as anti-Christian: the papist was the only heretic excluded from his wide tolerance. Milton shed far more of mediaeval Catholicism than did the Church of England. His great theological system, the De Doctrina Christiana, arose by a divorcing command from the ambiguous chaos of traditional Christianity. Milton rejected the Trinity, infant baptism and most of the traditional ceremonies, including church marriage; he queried monogamy and believed that the soul died with the body. He cannot reasonably be claimed as "orthodox.", 
Despite his inclination to cast Milton as a forerunner of Marx, Hill is justified in his reading of Milton's anti-authoritarianism, if we consider the products of Milton's left and right hands - the antiprelatical tracts and the poems and their reception history. While it was perhaps first evidenced in Lycidas, Milton worked out his antiprelaticalism in the pamphlets of the early 1640s. The reactions to The Doctrine and Discipline of Divorce by the Presbyterians in their Confession and by Thomas Edwards in his Gangraena are only two examples of the hostility that this controversialist incited. ${ }^{11}$ Milton's departure from a Calvinist-informed Puritanism led to his support in Areopagitica of freedom of expression, popular representation, and free-will theology; and throughout his life generally, Milton struggled to define himself in relation to the conflicting commitments of state and church. Milton's libertarianism fuelled his aversion to monarchy and to episcopacy, as captured in the line, "New Presbyter is but Old Priest writ Large." 12

Despite Milton's life-long efforts at redefining the politics of religion, literary critics and historians have focused primarily on his major epic, Paradise Lost, and specifically on the characterization of Milton's good God, who surprises readers with Sin in order to keep them in line. ${ }^{13}$ I propose in this case study to shift attention to Milton's engagement with the heterodox and the heretical in Samson Agonistes, a poem whose reception history has been underwritten by the "regenerationist pieties" of Miltonists committed to a conservative critical position. In the received tradition, the regenerationist pieties of Miltonists surface in a confident interpretation of Samson's death "as a proto-martyr's definitive act," 14 thus "improving the fit of Samson Agonistes with Christian orthodoxy and, in the process, diminishing its enquiring spirit, its interrogative element." 15 In a recent public statement on Samson Agonistes and the acts of violence that it seems at once to underwrite and undermine, Wittreich maintains that the truths of Samson Agonistes and of poetry generally are plural and not encapsulated by a singular statement or any one voice in a poem. "Poetry is a provocation to mental fight and spiritual adventure; Samson Agonistics is a mirror on every side of the conflict," Wittreich states: "it even helps explain why 9-11 happened."16

My investigation builds on Wittreich's discerning analysis and further disables our efforts at reading Samson Agonistes into coherence by exposing the poem's interpretive indirection. ${ }^{17}$ This interventionist approach to Samson Agonistes first considers the significance of the middle of this poem, which has been judged to have none. In an oft-quoted statement, Samuel Johnson announced definitively that Milton's tragedy "must be allowed to want a middle, since nothing passes between the first act and the last, that either hastens or delays the death of Samson." 18 Yet one can argue that what 
happens at the middle of the poem does hasten or delay the interpretive response to Samson's death if interpretation is the overriding action that constitutes the tragedy.

Situated at the heart of the poem is the encounter between Samson and Dalila - a drama of divided loyalties on both the domestic and national fronts. Milton analogizes Samson with the Israelite nation, an identification he made as early as Areopagitica in referring to the "noble and puissant Nation rousing herself like a strong man after sleep."19 Though Samson Agonistes cannot be reduced to an allegory of nationhood, it invites connections between Samson's tragedy and the New Israel's nascent nationalism, which emerged from the encounter with difference, the struggles for domination, and, paradoxically, the experience of defeat.

Israel's self-enslavement and external subjection are dramatized in particular through Samson's engagement with and repudiation of cultural difference - the contamination that threatens or weakens the chosen nation. Located between marriage and divorce in the poem, Samson confesses his impiety: "But I / Gods counsel have not kept, his holy secret / Presumptuously have publish'd, impiously, / Weakly at least, and shamefully: A sin / That Gentiles in thir Parables condemn."20 The reference to Samson's weakened state activates the Hebraic meaning of "Delilah" — dalal ("weaken" or "impoverish"). Samson's confrontation with Dalila reinforces the connection between the personal tragedy and national-political affairs by occasioning his remarks on their separate origins and allegiances: "I before all the daughters of my Tribe / And of my Nation chose thee from among / My enemies" (876-78). Milton conflates the early modern representation of "Delilah" as a harlot who lured men from religious or patriotic duty with the domestic treachery she commits as Samson's wife. But the exchange with Dalila in the tragedy is also a self-encounter, exposing the contradictory nature of the anti-hero himself. The admission that follows directly strikes at the heart of Samson and of Samson Agonistes: "[I] unbosom'd all my secrets to thee" (879). Already in the opening scene, Samson acknowledges his responsibility for the tragedy: "of what now I suffer / She was not the prime cause, but I myself" (233-34). Like Dalila, Samson is described as a "Vessel . . Gloriously rigg'd" (199-200), as shamefully garrulous (491), and as "Soft'n'd with pleasure and voluptuous life" (534). ${ }^{21}$ Moreover, Samson acknowledges his foolish behaviour throughout the poem, just as Dalila confesses her folly and rashness (907). But here, at the central moment in the tragedy, where Dalila comes into her own, her differences must be highlighted to justify divorce and the moratorium on mixed marriages. Dalila's impiety is also politicized when Samson charges her with abrogating "the law of nature, law of nations" (890), and 
reduces Philistia to "an impious crew / Of men conspiring to uphold thir state / By worse than hostile deeds, violating the ends / For which our country is a name so dear" (891-94). His adherence to the law of God and nation contrasts with her violation of both, in Samson's judgement.

\section{II}

Many critics have read the Samson-Dalila episode as a Christian allegory of a pilgrim's progress from sin to redemption. Samuel Hornsby exposes Dalila's insincerity by using De Doctrina as the basis for arguing that, though penitent, Dalila does not repent, and thus no renewal is possible. Laurie P. Morrow offers a similar argument by distinguishing between Dalila's and Samson's responses to their sinfulness, and allowing for the redemption of the latter. Dalila assumes a binary role as the "cause of Samson's fall and the agent of his regeneration" in Heather Asals's article, in which Dalila is deemed defensible only insofar as she contributes to Samson's regeneration. More recently, Achsah Guibbory explains that Milton's decision to make Dalila Samson's wife "not only emphasizes the strength of Samson's former attachment to the idolatry she represents. It allows Milton to evoke the radical reformist position, at the center of his earlier divorce tracts and now pointedly appropriate in the Restoration, that the good Christian must permanently separate from all idolatry." 22

Separation is central to the poem, marking the identity and the acts of Samson as Nazarite. But Samson Agonistes complicates the issue of Samson's vindication and redemption, while also qualifying the regenerationist pieties of the poem's critical tradition. Regenerationist pieties give way not only to the elusive motives for Samson's final act, an act that takes us "on a roller coaster of possible truths," 23 but also to Dalila's pieties, presenting us with another side of the conflict. At the heart of Samson Agonistes is Dalila's counter-narrative, in which she justifies her actions and produces her own version of history, one that will memorialise her piety, a term that invokes in this context the Latin pietas in the sense of loyalty to one's country. Unwilling to settle for the typological reading of her character, she seeks to direct the critical reception of her history. Dalila's famous speech is triggered by Samson's charge of betrayal and by his command that she "Bewail the falsehood, the pious works / It hath brought forth to make thee memorable / Among illustrious women, faithful wives" (955-57). At this pivotal moment, the "pious works" acquire the significance that Dalila herself ascribes to them when she announces that her heroism - though fated to remain unsung among the Jews - will be celebrated throughout Philistia: 
162 / Renaissance and Reformation / Renaissance et Réforme

Why do I humble thus myself, and suing

For peace, reap nothing but repulse and hate?

But go with evil omen and the brand

Of infamy upon my name denounc't

To mix with thy concernments I desist

Henceforth, nor too much disapprove my own.

Fame if not double-fac't is double-mouth'd,

And with contrary blast proclaims most deeds;

On both his wings, one black, the other white,

Bears greatest names in his wild aery flight.

My name perhaps among the Circumcis'd

In Dan, in Judah, and the bordering Tribes,

To all posterity may stand defam'd

With malediction mention'd, and the blot

Of falsehood most unconjugal traduc't.

But in my country where I most desire,

In Ecron, Gaza, Asdod, and in Gath

I shall be nam'd among the famousest

Of Women, sung at solemn festivals,

Living and dead recorded, who to save

Her country from a fierce destroyer, chose

Above the faith of wedlock bands, my tomb

With odors visited and annual flowers.

Not less renown'd than in Mount Ephraim,

Jael, who with inhospitable guile

Smote Sisera sleeping through the Temples nail'd.

Nor shall I count it heinous to enjoy

The public marks of honor and reward

Conferr'd upon me, for the piety

Which to my country I was judg'd to have shown.

At this who ever envies or repines

I leave him to his lot, and like my own. (965-96)

The speech confirms but also undercuts her loyalty, connecting the "doublefac't"/ "double-mouth'd" nature of fame to Dalila's and Dagon's duplicity. Moreover, Dalila is excised from Samson's life at line 999, her name erased from the Book of Life, and she is generally ignored in the reception history of poem. Yet the central space Milton creates for the speech teases us with the possibility of alternative forms of piety and competing standards of judgement. Though known "among the Circumcis'd" for her inconstancy and impiety, Dalila asserts her own sense of piety, and establishes a hierarchical relationship between piety to her country and wedlock bands, thus severing her ties with Samson. In the context of our times, Dalila's speech about the rewards of self-sacrifice for a nation deemed reprobate is a defence 
of the unthinkable and a prospect readily dismissed; and yet it is etched into the historical memory of Samson as the Israelite nation, ${ }^{24}$ while also helping to convert the poem into a mirror reflecting different sides of the conflict.

Fish remarks, in How Milton Works, that Dalila's motivation is "equally mysterious" as Samson's and that, consequently, "one can't help wondering, and wonder is finally a large part of our response to the scene and to the entire play." 25 In the section of his book that follows this observation, however, entitled "Where is the Middle?", ${ }^{26}$ Fish neglects Dalila's speech, which appears instead at the end of his chapter on Samson Agonistes, where he refutes her "most unsettling argument" on the basis that her intentions are fallacious. Dalila is not self-motivated to act, but prompted "by some abstract formula for behavior ... which is imposed from without and relieves her of the burden of making moral decisions." Consigning her memory to Philistine ritual and legend, Fish contends that Dalila is "nothing more than an object of [the Philistines'] interpretive desire." 27 But if we consider the poetry itself, we must concur with Wittreich's comments on the compelling discourse of Dalila's words. ${ }^{28}$ Empson, whose introductory critique of Neo-Christian criticism follows immediately upon a chapter that complicates the traditional representation of Delilah, concluded that Dalila's is "one of the noblest speeches in Milton"; Janel Mueller characterizes the rising final tone of Dalila's defence as "muscular"; and Paula Loscocco describes it as "Heroick." John Shawcross identified Dalila as a character who conveys "the uncertainties of religio-political action because of the multiple and right-wrong answers to the question, whose god is God?" I propose to develop this provocative insight, while resisting Shawcross's subsequent remarks that Milton's world of thought is marked by "consistencies of belief" and that God inevitably delivers those who, like Jesus, keep their faith or who, like Samson, experience renovation. ${ }^{29}$

Incompatibility and divided loyalties are justifications for divorce and for the separation of church and state. Milton's Samson is tragic because he feels the tension between his competing commitments, is at various times subject to each of their pulls, and knowingly chooses one of these loyalties and accepts the self-destructive consequences. However, conflicting commitments (to state, religion, and marriage vows) seem to pose no ethical dilemma for Milton's Dalila. In callously denying these tensions, she comes across as a villain, rather than a tragic hero, in the Hebrew narrative. Her self-generated epilogue/epitaph enables her to reclaim her history by imagining an afterlife alongside that of other militant Israelite heroines. "Introducing multiple levels of cultural and historical relativity, Dalila destabilizes Milton's construction of his text," Jacqueline DiSalvo recognizes; "the Philistines apparently can appreciate a woman's public, militant achievement. 
Moreover, by comparing herself to Jael, Dalila insinuates such relativity into biblical history itself, opening up that great historical gulf before Samson in which (as in Boadicea's era) women not only defended but judged Israel." 30 Though disabled and dismissed by the Israelite narrative, Dalila's story is woven into the lines of the poem and into the conflicted history of nationhood that the poem represents.

Though Dalila in Samson Agonistes is a voice of, and for, a counterculture, she has sisters in Western literature of the early modern period. The seventeenth-century counter-narratives in which they appear are not ones with which Milton was necessarily familiar, but they do offer evidence of alternative characterizations of the biblical Delilah, her Israelite counterparts, and their pious acts. The 1652 translation by John Paulet, Marquis of Winchester, of Pierre Le Moyne's 1647 La Galerie des femmes fortes (translated as The Gallery of Heroick Women) celebrates the heroism of Judith and of Jael, about whom Winchester writes: "There was ... prudence and conduct, addresse and courage in this action of Jahel; and particularly fidelity which is questioned was herein couragious and magnanimous: It was fortified with zeal, and consecrated to Religion"; "her first loyalty was to the Law of her forefathers ... and . . of that holy nation"; hers was "an Heroick Act of fidelity towards God whom she obeyed." 31 Dalila also has counterparts on the Restoration stage, whose performances, like hers, are as powerfully captivating as they are suspect. In John Dryden's Conquest of Granada - the first productions of which (December 1670 and January 1671) were concurrent with the printing of Samson Agonistes - Lyndaraxa is Dalila's representative. As the play's femme fatale, Lyndaraxa marches to the beat of the war drums, while plotting her next conquest:

Beat faster, Drums, and mingle Deaths more thick.

I'le to the Turrets of the Palace goe,

And add new fire to those that fight below.

Thence, Hero-like, with Torches by my side,

(Farr be the Omen, though,) my Love I'le guide.

No; like his better Fortune I'le appear:

With open Arms, loose Vayl, and flowing Hair, Just flying forward from my rowling Sphere.

My smiles shall make Abdalla more then Man; Let him look up and perish if he can. ${ }^{32}$

Lyndaraxa's unquenchable lust for power ignites the love of both Abdalla and Abdelmelech; ultimately only Alamazor — who is nevertheless also tempted by her histrionics - can rival her display of passionate grandeur. In her final moments, Lyndaraxa repeats Alamazor's boast, "Stand off; I 
have not leisure yet to dye" (Part I, 1.1.233), when she declares to Abdelmelech: "Dye for us both; I have not leysure now"; "Tell her I am a Queen" (Part II, 15.3.254, 261a). Indeed, she sustains her performance until the end of the play, when she savours the glory for which she longed: "I' me pleas'd to taste an Empyre "ere I goe" (Part II, 5.3.265). Ferdinand announces that Lyndaraxa will be rewarded for her role in the conquest of Granada: "Fair Lyndaraxa, for the help she lent / Shall, under Tribute, have this Government" (Part II, 5.3.234-35).

In a compendium of virtuous and evil women drawn from classical and biblical history, William Walsh in the late Restoration period demonstrates that the former constitute the majority. The "same Book that condemns Dalilah, cries up Deborah, and Jael," Walsh reminds his reader, and offers a corrective to the received biblical tradition: "For Dalilah I shall say nothing out of respect to the Scripture, that represents her as an Ill Woman; 'tis possible were she alive, she might tell you in her own defence, that what account you have of her, is from her profest Enemies: That however taking the thing as they tell it; if she did commit a piece of treachery, it was against an Enemy of her Country; and that it was very hard she should be so much run down for the same thing they have so much admired in Jael and Judeth, as well as every body else did in Marcus Brutus; she wou'd perhaps push her defence further, and tell you, that tho she deliver'd Samson to the Philistins to be kept Prisoner, yet she never drove a Nail through his head, nor cut it off." 33 In Samson Agonistes, Dalila likewise resists inscription into what Nabil Matar describes in Islam in Britain as an imperial, teleological construction of history - an extension of the "triumphant Biblical/Protestant view of the world." 34

\section{III}

At the end of the tragedy, Samson makes a final on-stage appearance in which he, like Dalila, defiantly asserts his separate identity. Personal and national salvation now depend on the renunciation of the other self, an act carried out all the more aggressively when the self is divided. The formulation of elect nationhood and, within that, personal election, remained a pressing issue for Milton and his contemporaries, marking the convergence of national sovereignty and religion. As Richard Helgerson has observed, England's national identity was defined as much by religious as by civic commitments. ${ }^{35}$ Puritans sought to resolve the problem of national unity by identifying internal rebellion with a foreign threat and by connecting English nationalism with international Protestantism. In the configuration of nationhood, certain groups were pushed outside the Christian pale, while others 
were invited into the fold. These conditions intensified in the Restoration era with the reintroduction of printing prohibitions, legislation designed to suppress dissent, and the re-emergence of a culture of intolerance. Judging by the burning of Eikonoklastes and the Defence by the common hangman, the barbarous dissonance of royalist pamphleteers in their response to The Ready and Easy Way, and the censorship of Paradise Lost, Milton himself was hardly immune to such repressive measures. ${ }^{36}$

Milton's major poems of the Restoration period resist the identification of the poet with a quietist politics or religion, which critics like C. S. Lewis discerned in his work. In the case of Samson Agonistes, the destruction of the Philistines' theatre/temple provides evidence of the revolutionary and religious zeal of the tragic hero. The final encounter with the Philistines is cast as a confrontation with cultural, religious, and political difference. Anticipating his severance from Philistine bonds and the race of the "unclean" in the last "act," Samson announces to the Officer who summons him to perform before the Lords that he will commit "Nothing dishonourable, impure, unworthy" (1424). "I am an Ebrew, therefore tell them, / Our Law forbids at thir Religious Rites / My presence" (1319-21), Samson asserts, and later: "A Nazarite in place abominable . . how vile, contemptible, ridiculous / What act more execrably unclean, profane" (1359-62). He refuses to "stain [his] vow of Nazarite" (1386) by yielding to the will of gentiles, the "unclean." The name "Nazarite" is derived from the Hebrew nazar, meaning "to separate" or "consecrate" (Num. 6:2-5), recalling the early reference to Samson as "a person separate to God, / Design'd for great exploits" (31-32). A reintegration into the realm of the elect necessitates his (clean) break from the Philistine race and empire. But the poem resists conforming neatly to a "triumphant Biblical/Protestant" master-narrative and refuses to sanction a correspondingly orthodox critical tradition.

The final scene develops the tension between competing reports of the motives for Samson's iconoclastic performance: by various accounts, Samson acts wilfully (1643); is "tangl'd in the fold / Of dire necessity" (1665-66); is self-motivated; or is directed by God to destroy the Philistine elite. The controversy over the last act is also a function both of the exegetical literature on the Judges account and of the unreliable readings of the Messenger and the Danites who make up the Chorus, which Samson at first mistakes for his enemies (110-14). Neither the Chorus nor Manoa, who also struggles to interpret the act, actually sees the destruction of the theatre. "In the absence of any witness or revelation that would lend them authority," Fish reminds us, the Danites" "words produce more problems than they resolve," 37 thereby opening the door to a range of interpretations. The poem then raises the possibility that both the Chorus and Manoa "contradict 
Samson into a heroism he is perhaps not meant to enjoy." 38 Moreover, it warns its on- and off-stage readers against declaring a definitive judgement on Samson's performance, a matter of contention that regenerationist critics attempt to override.

The controversy about Samson extends "beyond the fifth Act," as the reception history of the poem reaches into the contemporary period. In these times of heightened political tensions, the identities of Samson as terrorist / liberation fighter have come to the fore in Fish's characterization of the indeterminate motives of the tragic hero. Here Fish dismisses the "regenerationist reading of the play (of which Manoa and the Chorus are the first proponents)," one that unites God and Samson "in the 'great event' of whose meaning everyone is so confident." Instead, decides Fish, "[t]he only wisdom to be carried away from the play is that there is no wisdom to be carried away, and that we are alone, like Samson, and like the children of Israel, of whom it is said in the last verse of Judges: "every man did that which was right in his own eyes." Samson's desire to conform to the divine will establishes the indisputable rightness of his action: "No other standard for evaluating it exists." ${ }^{39}$ Fish's representation is unsettling for various reasons, including the lack of standards he allows for judging Samson's final act. In a recent essay in the Times Literary Supplement, John Carey argues that Fish's claim about the omission of external referents, in particular, paints a very disturbing picture. Fish's insistence that Samson can be judged only by Samson's own criteria even strikes Carey as "monstrous - a license for any fanatic to commit atrocity. ... When the Sept. 11 attacks occurred, they seemed a 'devilish implementation' of Fish's arguments." 40

Certainly, as poetry, Samson Agonistes challenges any Christian or even moral obligation to read the final act in regenerationist terms. But in the aftermath of "9.11," the problematizing of Samson's afterlife, which destabilizes the narrative of regeneration, becomes a breech of faith and political heresy, Carey's reading implies. In these times, the interpretive indirection introduced by the elusive standards of judgement in the poem — an indirection that Fish and Carey resist for very different reasons — is particularly unsettling. Like Dalila's counter-narrative, competing interpretations, "conflicting loyalties" 41 or the presence of powerful others that threaten one's self-identity impiously mock the purity of the tragic mode. Ultimately, then, if "September 11 has changed Samson Agonistes" 42 - as I believe to be the case - it is because critical practice has become an act that heretically cries up the coexistence of multiple truths and mirrors the different sides of the conflict, despite or in the face of resistance to such heretical possibilities. 
168 / Renaissance and Reformation / Renaissance et Réforme

\section{Notes}

1. John P. Rumrich, "Uninventing Milton," Modern Philology 87 (1990): 249-65; Rumrich, Milton Unbound: Controversy and Reinterpretation (Cambridge: Cambridge University Press, 1996), pp. 1, 4, 7. In response to the dissatisfaction with the New Critical conception of Milton, scholars fashioned what Robert Thomas Fallon calls a "'new' Milton, one derived largely from the evidence of his works. Out of the ashes of the disagreeable Puritan there arose Milton the Whig, Milton the Liberal, and finally Milton the Pacifist" ("Milton's Epics and the Spanish War: Toward a Poetics of Experience," Milton Studies 15 [1981]: 6). D. D. Guttenplan has observed, "In his lifetime the poet and pamphleteer John Milton was called many things: divinely inspired, blasphemous, a Puritan, a libertine, a flatterer, a propagandist and a revolutionary" ("Is Reading Milton Unsafe at Any Speed?" [New York Times, 28 December 2002], p. B9).

2. William Empson, Milton's God (London: Chatto and Windus, 1961), p. 229.

3. Rumrich, Milton Unbound, p. 1; Christopher Hill, Milton and the English Revolution (New York: Viking, 1977), p. 3. Hill's characterization informed the work of various distinguished Miltonists, including Sharon Achinstein, David Loewenstein, and Rumrich, who, like Hill, emphasize Milton's interconnected religious and political "heterodoxy" (Hill, Milton, p. 3). See Sharon Achinstein, "The Drama of Dissent," Milton Studies 33 (1996): 133-58, and Literature and Dissent in Milton's England (Cambridge: Cambridge University Press, 2003); David Loewenstein, Representing Revolution in Milton and his Contemporaries (Cambridge: Cambridge University Press, 2001); and John Rumrich, "Radical Heterodoxy and Heresy," in A Companion to Milton, ed. Thomas N. Corns (Oxford: Blackwell, 2001), pp. 141-56. Scholars who locate Milton in terms of Hebraism and Judaism have also resisted the Neo-Christian bias. Jason Rosenblatt, Michael Lieb, Regina Schwartz, Joseph Wittreich, and Jeffrey Shoulson, among others, have investigated the dynamic conversation between the Hebrew and Christian traditions, both of which are "fraught with tensions," as well as interrelated, despite the cultural forces that insist on their distinctiveness (Jeffrey S. Shoulson, Milton and the Rabbis: Hebraism, Hellenism, and Christianity [New York: Columbia University Press, 2001], p. 5).

4. C. S. Lewis, A Preface to Paradise Lost (1942; rpt. London: Oxford University Press, 1963), p. 65. Joseph H. Summers recognized that "It is a rare critic who can resist the tendency to reduce an admired figure to his own image" ("Milton and the Cult of Conformity," in Milton: Modern Judgements, ed. Alan Rundrum [London: Macmillan, 1968], p. 30).

5. Empson, pp. 9, 18-19, et passim.

6. Blair Worden, "Milton's Republicanism and the Tyranny of Heaven," in Machiavelli and Republicanism, ed. Gisela Block, Quentin Skinner and Maurizio Viroli (Cambridge: Cambridge University Press, 1990), p. 243.

7. Stanley Fish, How Milton Works (Cambridge, MA: Harvard University Press, 2001), p. 14.

8. Ibid., p. 5 .

9. Joseph Wittreich, “'He Ever was a Dissenter': Milton's Transgressive Maneuvers in Paradise Lost," in Arenas of Conflict: Milton and the Unfettered Mind, ed. Kristin Pruitt McColgan and Charles W. Durham (Selinsgrove: Susquehanna University Press, 
1997), p. 36, and Shifting Contexts: Reinterpreting Samson Agonistes (Pittsburgh: Duquesne University Press, 2002), p. xiii.

10. Hill, Milton, p. 3.

11. See Ann Hughes, “Approaches to Presbyterian Print Culture: Thomas Edwards' Gangraena as Source and Text," in Books and Readers in Early Modern England: Material Studies, ed. Jennifer Andersen and Elizabeth Sauer (Philadelphia: University of Pennsylvania Press, 2002), p. 100, who notes (p. 113n8) that Thomas Edwards's Gangraena (1646) cites The Doctrine and Discipline of Divorce in Part I, p. 34.

12. "On the New Forcers of Conscience under the Long Parliament," John Milton: Complete Poems and Major Prose, ed. Merritt Y. Hughes (New York: Odyssey Press, 1957), 1. 20.

13. See Stanley Fish, Surprised By Sin: The Reader in Paradise Lost (New York: St. Martin's, 1967).

14. Dennis Kezar reviews the regenerationist-sceptical/revisionist debate in Milton studies in "Samson's Death by Theater and Milton's Art of Dying," ELH 66 (1999): 297. See also Barbara Kiefer Lewalski, "Milton's Samson and the 'New Acquist of True [Political] Experience," Milton Studies 24 (1988): 233-52, and Stanley Fish's fine essay, "Spectacle and Evidence in Samson Agonistes," Critical Inquiry 15 (1989): 557n2. (This essay is reprinted in How Milton Works, pp. 432-73.)

15. Wittreich, Shifting Contexts, p. xiii.

16. Joseph Wittreich, "Why Milton Matters," Milton Society of America, Modern Language Association Convention, December 2002, New York, NY. I am grateful to Professor Wittreich for providing me with a copy of his typescript.

17. See Fish, "Spectacle."

18. Samuel Johnson, Rambler 139 (16 July 1751), The Complete Prose Works of Samuel Johnson, ed. W. J. Bate and Albrecht B. Strauss, 16 vols. (New Haven, CT: Yale University Press, 1969), 4: 376.

19. Areopagitica, Complete Prose Works of John Milton, ed. Don Wolfe et al., 8 vols. (New Haven, CT: Yale University Press, 1953-82), 2: 558. All citations of Milton's prose are taken from this edition and documented parenthetically.

20. Samson Agonistes, John Milton: Complete Poems and Major Prose, ed. Merritt Y. Hughes (New York: Odyssey Press, 1957), 11. 495-500. Subsequent references are to this edition, with line numbers cited parenthetically in the text.

21. See Jackie DiSalvo, “Intestine Thorn: Samson's Struggle with the Woman Within,” in Milton and the Idea of Woman, ed. Julia Walker (Chicago: University of Illinois Press, 1988), pp. 211-29.

22. Samuel Hornsby, "Penance of the Hyaena," Philological Quarterly 57 (1978): 353-58; Laurie P. Morrow, "The 'Meet and Happy Conversation': Dalila's Role in Samson Agonistes," Milton Quarterly 17 (1983): 38-42; Heather Asals, "In Defense of Dalila: Samson Agonistes and the Reformation Theology of the Word," JEGP 74 (1975): 183-94, esp. p. 183; Achsah Guibbory, Ceremony and Community from Herbert to Milton: Literature, Religion, and Cultural Conflict in Seventeenth-Century England (Cambridge: Cambridge University Press, 1998), p. 223.

23. Stephen B. Dobranski, Milton, Authorship, and the Book Trade (Cambridge: Cambridge University Press, 1999), p. 56. 
170 / Renaissance and Reformation / Renaissance et Réforme

24. See Linda Gregerson on the nation's "collective aptitude for retentive imitation" ("Colonials Write the Nation: Spenser, Milton, and England on the Margins," in Milton and the Imperial Vision, ed. Balachandra Rajan and Elizabeth Sauer [Pittsburgh, PA: Duquesne University Press, 1999], p. 188).

25. Fish, How Milton Works, p. 401.

26. Ibid., pp. 402-14.

27. Ibid., pp. 426, 427, 470 .

28. Wittreich, Shifting Contexts, pp. 142-44.

29. Empson, p. 221; Janel Mueller, "Just Measures: Versification in Samson Agonistes," Milton Studies 33 (1996): 70; Paula Loscocco, “'Not Less Renown'd Than Jael': Heroic Chastity in Samson Agonistes, ” Milton Studies 40 (2001): 188; John Shawcross, The Uncertain World of Samson Agonistes (Cambridge: B. S. Boydell, 2001), pp. 80, 141.

30. Jacqueline DiSalvo, "Make War Love: On Samson Agonistes and The Caucasian Chalk Circle," Milton Studies 24 (1988): 225.

31. John Paulet, Marquis of Winchester, The Gallery of Heroick Women. Written in French by Peter Le Moyne, of the Society of Jesus. Translated into English by the Marquesse of Winchester (London, 1652), p. 25; quoted in Loscocco, p. 185.

32. John Dryden, The Conquest of Granada (1672), The Works of John Dryden, 20 vols. (Berkeley: University of California Press, 1956- ), vol. 11, Part I, 3.1.260-69. Subsequent references are included parenthetically in the text.

33. William Walsh, A Dialogue Concerning Women. Being a Defence of the Sex (London 1691), pp. 82, 80-81.

34. Nabil Matar, Islam in Britain 1558-1685 (Cambridge: Cambridge University Press, 1998), p. 190

35. Richard Helgerson, Forms of Nationhood: The Elizabethan Writing of England (Chicago: University of Chicago Press, 1992).

36. See Gerald R. Cragg, Puritanism in the Period of the Great Persecution 1660-1688 (Cambridge: Cambridge University Press, 1957), and Francis Blackburne's compilation of critical responses to Milton by Restoration and eighteenth-century writers who admired Milton's poetry while denouncing his political views (Memoirs of Thomas Hollis, Esq, 2 vols. [London: J. Nichols, 1780], 1: 135-53).

37. Fish, "Spectacle," p. 569.

38. Joseph A. Wittreich, Interpreting Samson Agonistes (Princeton, NJ: Princeton University Press, 1986), p. 121.

39. Fish, How Milton Works, pp. 473, 426.

40. John Carey, "A Work in Praise of Terrorism: September 11 and Samson Agonistes," Times Literary Supplement 6, no. 5188 (6 Sept. 2002): 15.

41. Fish, How Milton Works, p. 12.

42. Carey, p. 16. 